\title{
"To Make the World a Better Place": Giving Moral Advice to the Jewish State as a Manifestation of Self-Legitimized Antisemitism among Leftist Intellectuals
}

\begin{abstract}
Antisemitism is hostility toward Jews as Jews. It is easily detected and condemned when it manifests itself explicitly in discriminatory hate speech. When, however, it is articulated in the garb of anti-Israelism or anti-Zionism by intellectuals-often academics claiming not to be antisemitic themselves-civil society often finds it hard to perceive the antisemitic semantics lurking beyond sophisticated utterances. Even more so, educated antisemites claim to act according to high ethical values, referring to the moral categories of the Western world in order to deny their antisemitic attitude. Using philosophical argumentation patterns and the strategy of self-legitimization, they call upon values such as humanity and reason, and striving for world peace. "For the sake of humankind" or "for the benefit of world peace," they demand the alteration of Jews, Judaism, and connected to this, the modification or "improvement" of the Jewish state. Singling out and bashing Israel by evoking traditional Judeophobic stereotypes is by now the most common strategy of contemporary antisemitism. This kind of camouflaged antisemitism is readily accepted in society, and as such, is more dangerous than vulgar hate speech. Even more so, if it is articulated by well-known intellectuals. This article explains the main argumentation patterns of educated antisemitism with both its denial and self-justification. It refers to data from corpus studies and discusses the case of Achille Mbembe, which launched a larger debate on freedom of expression and criticism regarding the state of Israel versus Israel-related antisemitism.
\end{abstract}

\section{Contemporary Antisemitism and its Denial}

In the twenty-first century, the official ban on antisemitic utterances has lost its influence in many discourse realms, and the articulation of traditional antisemitic stereotypes has increased significantly. In fact, antisemitism turns out to be a worldwide phenomenon on the rise. Jews have been attacked and killed in Belgium and in France, spit upon in Rome and in London. In Berlin, there is growing hostility (both verbal and physical) toward Jews on the streets of certain areas. Jewish institutions in Germany have to be kept under constant police supervision. International polls show that the attitude toward Israel has become extremely hostile and aggressive everywhere; this hostility is based on Judeophobic stereotypes and an age-old bias in new garb. All over the world, anti-Israel boycott movements have spread, gaining influence especially in left-wing circles but also in parts of Christian churches and public institutions. There is a virulent 
campus antisemitism in both US and British colleges and universities that claims to be critical of Israel but in fact is based on hostility toward Jews and uses the same demonizing verbal strategies as right-wing extremists and neo-Nazis.

However, despite the experience of the Shoah, there is a strong tendency to deny the very existence of contemporary hostility against Jews in the German society. ${ }^{1}$ This goes along with the delegitimization of the IHRA Working Definition that includes all contemporary manifestations of antisemitism, among them forms of anti-Israelism and anti-Zionism. Antisemitism is expressed in various forms stemming from diverse political and ideological directions. Jew-hatred may be articulated explicitly as hate speech and implicitly in more indirect verbal acts that are declared as "freedom of speech." However, the concept of antisemitism in public opinion still very much rests on the historical phenomenon of racism and its continuity in right-wing circles. Many left-wing intellectuals find it hard to accept that there is Jew-hatred outside of the right-wing political spectrum in post-Shoah Germany. Thus, "true antisemitism" is seen and recognized by them only at the outer edges of society. The fact that today's judeophobia has developed into new manifestations is still widely ignored or vehemently marginalized. In particular, the articulation of traditional antisemitic stereotypes by projecting them onto Israel has increased significantly. ${ }^{2}$ Claiming to just criticize Israeli politics, but using at the same time Judeophobic stereotypes, is by now one of the most common, if not the predominant manifestation of contemporary Jew-hatred. At the same time, there is a remarkable rejection of the results from research on antisemitism in mainstream society. One of the dominant strategies of dealing with left-wing and educated antisemitism as Anti-Zionism/ anti-Israelism in German public discourse is to deny the very existence of it. In Germany, this became quite evident in a public debate in April 2012, on a poem by the German Nobel laureate Günter Grass in which he attacked and bashed Israel (and not Iran) for being a "threat to world peace" because of its nuclear program. Although the poem borrowed Judeophobic clichés and projected them onto Israel, many people commenting on it were not able or willing to recognize anything antisemitic in the text. Since the text focused on the nuclear power of Israel, and the word Jew did not occur once, many defended it as "simply critical," "giving just facts," or a "manifestation of free speech." Claiming to just criticize Israeli politics but simultaneously using Judeophobic stereotypes

1 Cf. M. Schwarz-Friesel and J. Reinharz, Inside the Antisemitic Mind: The Language of JewHatred in Contemporary Germany (Boston: University Press of New England, 2017), 285ff.

2 Cf. M. Schwarz-Friesel, “The Persistence of European Antisemitism,” BESA Center Perspectives Paper, no. 1067, January 18, 2019, https://besacenter.org/perspectives-papers/european-antisemitism/. 
and argumentation patterns is by now one of the most prominent and at the same time most commonly denied manifestation of contemporary Jew-hatred. The debate flamed up anew in January 2013, when Jacob Augstein, a leftist journalist and columnist for Spiegel Online, appeared on the Wiesenthal list for “2012 Top Ten Antisemitic/Anti-Israel Slurs,” ranking him ninth for his public attacks on the state of Israel. Although Augstein admitted never having been to Israel, he frequently condemned and demonized the country. Having very little knowledge regarding the Israeli-Palestinian conflict, he nevertheless felt competent enough to bash Israel. He stated, for instance, that orthodox Jews follow "the law of revenge" (thus repeating a very old anti-Jewish stereotype) and implied that some ominous Jewish force determines political decisions through "lobby groups" (hence, leaning on conspiracy phantasies). He called Gaza a "camp" and accused Israel of "breeding terrorists." This kind of language used among the moderates of society and articulated in mainstream press can trigger and reinforce stereotypical thinking and evoke sentiments against Jews even if such processes are not intended. Since language in mass media has a mental power of its own and is capable of subconsciously influencing the collective mind to a large degree, it is not a matter of the intention that lies behind a text but above all the text and its content itself, its cognitive implications, and associations that make it verbal antisemitism or not.

A third debate, even more forceful and aggressive, arose in in April 2020 concerning the anti-Israeli texts of Achille Mbembe, a renowned African scholar in the field of post-colonial studies. ${ }^{3}$ The text of Mbembe employed a rhetoric usually found in the writings of anti-Zionist antisemites, since they implicitly invoke stereotypes of classical Jew-hatred. Further, he communicated conceptualizations of the conflict with the Palestinians that were apt to minimize and belittle the Holocaust. In Mbembe's book Politics of Enmity and his foreword "On Palestine" to the book Apartheid Israel: The Politics of an Analogy, he writes that "[t]he occupation of Palestine is the biggest moral scandal of our times, one of the most dehumanizing ordeals of the century we have just entered, and the biggest act of

3 The historian and philosopher from Cameroon was honored many times as an important figure of post-colonialism. He was awarded several prizes in Germany and was called "one of the most important thinkers on the African continent." Hence, Mbembe with all his "outstanding research achievements" has some influence in academic and public circles. His rhetoric has impact on people. He showed no insight that his texts were at least dubious. Currently, the debate is still ongoing. All in all, it has done great damage to scientific and social work combating antisemitism. 
cowardice of the last half-century." ${ }^{4}$ Adding, "since what they [the Israelis] are willing to do is to go all the way-carnage, destruction, incremental extermination-the time has come for global isolation." ${ }^{5}$ Furthermore, he uses demonizing superlatives and metaphors that trigger implications of classical Judeophobic semantics.

Therefore, a politician from the FDP (the German liberal party) criticized the organizer of a major international cultural festival for inviting Achille Mbembe to give a speech at the opening. When Mbembe was accused of spreading hatred of Israel and the relativization of the Holocaust in his texts, it triggered a fierce and highly emotional debate about antisemitism, the use of analogies, and the uniqueness of the Holocaust. Many in German mainstream media and in the academic world rushed to defend Mbembe without even having read his columns or considering the impact of such a rhetoric. Even more disturbing, most of Mbembe's public defenders claiming to argue for the "freedom of speech" showed neither competence nor any knowledge about verbal antisemitism and its numerous modern expressions. Not only did the ongoing debates keep drifting away from the insight of research, they also revealed a pattern common and typical of left-wing discourse on this topic. Hence, we will delve into the Mbembe case later.

\section{The Israelization of Antisemitism and its Denial}

Overall, research on antisemitism sees the persistence of age-old classical stereotypes and argumentation patterns in modern discourse, in spite of coping with the past after the Holocaust: Jews and/or Israelis are described as murderers of little children, blood libel users, shylocks, traitors, liars, land robbers, disloyal strangers, as a collective with specific characteristics. Jews are still conceptualized by antisemites as "the others," as "the most vile and mean creatures on earth.” They are perceived as "a threat to humankind.” Anti-Zionists like to claim that their attitude is something new, something completely unrelated to the old Jew-hatred, which they pretend to reject. They usually claim that they oppose Israel because of its supposed cruel treatment of the "Palestinians" or of its “colonizing Arab land," or of being an "apartheid” state. In this view, it is Israel's

4 A. Mbembe, "On Palestine," in Apartheid Israel: The Politics of an Analogy, ed. J. Soske and S. Jacobs (Chicago: Haymarket Books, 2015), viii.

5 Ibid. 
conduct that gives rise to hostile feelings toward the Jewish state and that makes them harsh critics. Going a step further, they claim to have a moral duty to sharply criticize Israel. This de-realized stance obviously re-activates the age-old stereotype that Jews are themselves responsible if anti-Jewish feelings occur. The experience of Auschwitz and years of education did not change the age-old hostile conceptualization of Jews: We see the recurring conceptualization of "Jews are the evil in the world" re-activated as "Israel is the evil in the world," as in the following email to the Israeli embassy: "Israel is an illegitimate evil state and threatens world peace” (IBD; Gaza-14). And a journalist, member of a left-wing party writes that "Only by the complete dissolution of the illegal Zionist 'construct,' peace will come to the world” (IBD; Gaza-2014).

Antisemitism is not primarily a phenomenon found among neo-Nazis or Muslim fundamentalists but present in all levels of society. More than fifty percent of the antisemitic writings to the Central Council of Jews in Germany and to the Israeli embassy in Berlin come from people belonging to the so-called moderates of society: students, architects, bankers, lawyers, doctors, priests, and so on, often highly educated persons with an academic background who know well what happened in the Holocaust. ${ }^{6}$ Those antisemites pose as anti-antisemites, fiercely denying being antisemitic. "Israel's cruelty...Now I understand why Jews are said to be rotten, brutal, lying, greedy and ruthless. Many of my classmates feel exactly the way I do!" states an email to the embassy of Israel in Berlin from an eighteen-year-old high school student who "is politically left," "works for Amnesty International," "is against all kinds of racism.” Thus, modern judeophobia is not necessarily connected to racism and xenophobia, and to combat antisemitism in an effective way, that fact has to be acknowledged.

There is a fierce antisemitism from the left ${ }^{7}$ that appears camouflaged as "criticism of Israel" or as "Anti-Zionism," and educated people from the mainstream also articulate verbal antisemitism: The following email to the Central Council of Jews in Germany was sent by a law professor: “... all your crimes ... The reason for this must be the Zionist idea to be the chosen people." Here, we see one of the most dominant argumentation patterns in antisemitic discourse: the conflation of Jews and Israelis, that goes along with ascribing collective responsibility for everything bad going on in the world to the "collective

6 Cf. Schwarz-Friesel and Reinharz, Inside the Antisemitic Mind.

7 See D. Hirsh, Contemporary Left Antisemitism (London: Routledge, 2017); and L. Rensmann "The Peculiar Appeal of the 'Jewish Question': The Case of Left Antisemitism," Antisemitism Studies 3, no. 2 (2020): 343-71. 
Jew." This "Israelization of antisemitism"8 proves to be the predominant conceptual pattern and communicative narrative in contemporary Jew-hatred.

\section{Educated Antisemitism and its Long Tradition}

Seventy-five years after the Holocaust, hostility against Jews is once again a phenomenon of worrying magnitude in Germany and in the world. The attack on the synagogue in Halle and the rampant growth of antisemitic conspiracy phantasies circulating online and in the streets in response to the COVID-19 pandemic are only the most recent and most alarming indications of what scholars studying antisemitism have been warning about for more than a decade: the taboo over antisemitic language has been eroding steadily and not only on the fringes of society; ordinary citizens openly and assertively express anti-Jewish ideas. Yet those who take up the fight against antisemitism in politics, the media, and the public sphere often misconstrue the causal relationship between the educated middle class and the social margins, a misapprehension reflected by headlines such as "Antisemitism Has Arrived in the Center."

Historically speaking, anti-Jewish ideas have in fact always originated in the center, in the writings of academics and educated authors, and from there spilled out into the street. That is because hatred of Jews is a cultural phenomenon first and foremost and only secondarily a matter of social psychology, and Judeophobic tropes are an integral element of Western religious and intellectual history. And so it bears repeating that anti-Jewish ideas and verbal patterns have been firmly and deeply rooted in Western cultural memory for two millennia precisely because art and culture-not just uneducated marginal figures but the thought leaders, the masterminds whose thinking has informed the cultural sphere of society-have perpetuated them over the centuries. ${ }^{9}$ This tradition is still alive, as

8 See M. Schwarz-Friesel and J. Reinharz, “The Israelization of Antisemitism," The Jerusalem Post, February 16, 2017, https://www.jpost.com/opinion/the-israelization-of-antisemitism481835.

9 For much of the long history of anti-Judaism, learned churchmen and priests were virtually the only ones who knew how to read and write and articulated Judeophobic ideas in their writings and sermons. That is why antisemitism is not a problem of the undereducated, as commentators are fond of claiming; in fact, nothing could be further from the truth. Education does not confer immunity to anti-Jewish resentment. In the US, for instance, the campuses of elite universities have recently emerged as the hotbeds of an alarming upsurge in antisemitism. See, e.g., M. Schwarz-Friesel, “Antisemitismus an Universitäten: die lange Tradition gebildeter Judenfeindschaft,” Gender, Politik, Universität. Gegen Diskriminierung an Hochschulen 1 (2016): 22-23, 
every debate over antisemitism of the past several years, including, most recently, the emotionally charged Mbembe controversy, has illustrated afresh. The debate once again showed that something is going seriously wrong in Germany. After the Halle attack on Yom Kippur in 2019, one might have expected uniform condemnation of all Judeophobic comments, including those disguised as "criticism of Israel." One might have hoped that academics who resort to crude analogies (e.g., comparing Islamophobia with Jew hatred) and antisemitic tropes to demonize the Jewish state or irresponsibly toy with such linguistic structures would be met with adamant opposition. Instead, some public voices have defended and even endorsed such rhetoric, seconded by the now obligatory signature collections supporting the "freedom of opinion" and lending legitimacy to unequivocally anti-Israel movements like BDS.

\section{Implicit Antisemitism and Camouflage Technique}

There is hardly any difference between the texts of right, left, and mainstream educated antisemites: they evoke the same stereotypes, and they use the same patterns of argumentation. The difference lies only in the style-the less radical language use-but the semantics of devaluation are the same. The antisemitic texts of mainstream writers are not as vulgar as an extremist's writings, they avoid death threats but instead propose other genocidal solutions in the name of "humanity." Lethal "solution plans" are being transferred from "the Jewish question" to the state of Israel. "Dissolve the state of Israel with the help of UN!" (a left-wing "Peace Activist" to the Israeli embassy in Berlin) articulates the old antisemitic "salvation phantasy." Antisemites from mainstream society prefer to use indirect speech acts (rhetorical questions, allusions of specific kinds, and reference shifting) to express their hostility toward Jews and/or the state of Israel. This implicit verbal antisemitism, however, invokes the same traditional stereotypes as in the texts from extremists. Hence, those indirect forms are as dangerous to the collective mind of a society as direct, manifest forms of Jew-hatred.

In today's most important space of social communication, the Web 2.0, antiJudaism manifests itself with unprecedented frankness and candor-as what it has always been and still is: resentment directed against the existence of Jews

http://www.audiatur-online.ch/2016/06/16/antisemitismus-an-universitaeten-die-lange-tradi tion-gebildeter-judenfeindschaft/. 
in the world. ${ }^{10}$ As stated, antisemitism is not a prejudice, it is a singular unified belief system, a pure phantasm, since the cultural concept of the JEW in the minds of antisemites is an abstraction just as their image of Israel is a construct: the product of processes of projection. And so, right now, fantasies of conspiracy and annihilation flood the worldwide web. Minute by minute, the slogans are recirculated: "Israel bred the coronavirus," "Smash Israel!", “Tod dem Zionismus," "Death to Israel," "Free Palestine."11

No less alarming and perhaps even more profoundly concerning than the hate that people spew online are the irresponsible voices from the cultural scene and the academy who bring their capacity to deny or reinterpret the hatred of Jews in its currently dominant form, anti-Israel antisemitism. ${ }^{12}$ Studies have shown that this form has been especially prevalent for years, which is why we scholars have long diagnosed an "Israelization of antisemitism": hatred toward Israel has become the glue holding all present varieties of Judeophobia together. Yet if there is one epithet that "renowned," "well-known," "prizewinning" come-

10 M. Schwarz-Friesel, Judenhass im Internet: Antisemitismus als kulturelle Konstante und kollektives Gefühl (Berlin: Hentrich \& Hentrich, 2019); English synopsis: https://www.linguistik.tuberlin.de/fileadmin/fg72/Antisemitism_2.0_short_version_final.pdf.

11 In many contexts, "Free Palestine!" is code for the incitement to make Israel vanish from the map, based on the slogan "From the river to the sea, Palestine will be free!" Such codes have been a fixture for many years of antisemitic communicative indirection, which camouflages radical content by disguising it in de-radicalized form; see, e.g., L. Rensmann, "Zion als Chiffre: Modernisierter Antisemitismus in aktuellen Diskursen der deutschen politischen Öffentlichkeit,” in Gebildeter Antisemitismus, ed. M. Schwarz-Friesel (Baden-Baden: Nomos, 2015), 93-116. See also M. Schwarz-Friesel, "Educated Anti-Semitism in the Middle of German Society: Empirical Findings," in Being Jewish in 21st-Century Germany, ed. O. Glöckner and H. Fireberg (Berlin: De Gruyter, 2015), 165-87; and A. H. Rosenfeld, ed., Anti-Zionism and Antisemitism: The Dynamics of Delegitimization (Indiana: Indiana University Press, 2019).

12 See, e.g., M. Zuckermann, “Antizionismus, Antisemitismus und Israelkritik sind drei Paar Schuhe," interview by J. Nichelmann, Deutschlandfunk Kultur, April 25, 2020. https://www. deutschlandfunkkultur.de/moshe-zuckermann-zur-debatte-um-mbembe-antizionismus.1013.de. html?dram:article_id=475490; and M. Brumlik, "Vergleich bedeutet nicht Gleichsetzung," interview by T. Lieske, Deutschlandfunk, May 4, 2020, https://www.deutschlandfunk.de/solid aritaetsbrief-fuer-achille-mbembe-vergleich-bedeutet.691.de.html?dram:article_id=475977. See also E. Friesel, "The Inverted Ideological Pyramids of Anti-Zionist Jews: The Case of Moshe Zuckermann,” BESA Center Perspectives Paper, no. 436, March 30, 2017, https://besacenter.org/ perspectives-papers/inverted-ideological-pyramids-anti-zionist-jews-case-moshe-zuckermann/; and E. Friesel, "Jews against Zionism/Israel: On the Ambivalences of Contemporary Jewish Identity," in Comprehending and Confronting Antisemitism: A Multi-Faceted Approach, vol. 1 of An End to Antisemitism!, ed. A. Lange, K. Mayerhofer, D. Porat, and L. H. Schiffman (Berlin: De Gruyter, 2019), 427-40. 
dians, writers, musicians, academics, and journalists who populate the postHolocaust society indignantly reject, it is "antisemite."

Instead, whenever antisemitic language is exposed to be just that and faces criticism, the defendant invariably responds with well-rehearsed protestations that he or she is "aghast," "distraught," even "stunned" by the charge of antisemitism. Extensive research has shown these defensive strategies to be an integral component of the discourse of antisemitism denial. ${ }^{13}$ Fully aware of the dangerous persuasive force of the verbal patterns they employ, public figures play with rhetorical fire; their defenders lionize them as champions of the freedom of speech. Intellectuals and university graduates keep regurgitating the same arguments and injecting them into the public discourse. These contentions have no basis in fact, are myopically trained on the surreal enemy stereotype ISRAEL, and are impervious to empirical data or the findings of experts: ${ }^{14}$ "criticism of Israel," they claim, is off limits (a notion not borne out by reality); political criticism must not be equated with hatred of Jews (as though anyone making a serious argument had ever identified one with the other); and it is ultimately difficult to draw a neat line between antisemitism and criticism of Israel (even though the scholarship has long presented analytical criteria and decoding categories for a precise distinction ${ }^{15}$ ).

Yet many artists and academics, it appears, find it unthinkable that educated, sophisticated, liberal-minded voices might be spouting antisemitic ideas.

13 See Schwarz-Friesel and Reinharz, Inside the Antisemitic Mind, chapter 10.

14 For a typical representative of these amateur contributions to the debate, see Yossi Bartal in conversation with Inge Günther, Frankfurter Rundschau, June 24, 2019: "I experience the climate in Germany, especially after the Bundestag resolution on the BDS boycott movement, as one in which any fundamental critique of the situation in Israel/Palestine is marginalized or even criminalized.” This climate, Bartal asserts, "stifles a free discourse.” Y. Bartal, "Ein freier Diskurs wird erstickt," interview by I. Günther, Frankfurter Rundschau, June 24, 2019, https://www.fr.de/ kultur/interview-yossi-bartal-juedisches-museum-berlin-12665805.html. Reality challenges such claims: legitimate critique of Israeli actions is widely and sharply expressed in the media and political discussions and by no means "criminalized" as antisemitism. There is virtually no issue that is debated more freely and with greater intensity than the Middle East conflict. See P. Woldin, "Die Medien kritisieren kaum ein Land so oft wie Israel," Zeit Online, August 4, 2017, https://www.zeit.de/politik/deutschland/2014-08/israel-medien-kritik. Moreover, an empirical study has demonstrated that the frequently invoked taboo over criticism does not exist; see M. Schwarz-Friesel, Judenhass im Internet: Antisemitismus als kulturelle Konstante und kollektives Gefühl (Berlin: Hentrich \& Hentrich, 2019), 135ff.

15 See Schwarz-Friesel and Reinharz, Inside the Antisemitic Mind, chapters 2-4, and A. Lange, K. Mayerhofer, D. Porat, and L. H. Schiffman eds., Comprehending and Confronting Antisemitism: A Multi-Faceted Approach, vol. 1 of An End to Antisemitism! (Berlin: De Gruyter, 2019). 
"Witch hunt," "lynching," "repression," "McCarthyism,"16 academics have brought out as the reversal of perpetrator and victim in support of Mbembe, without looking into what research has to say. ${ }^{17}$ Genuinely relevant research distinguishes, for good reason, between verbal antisemitism (i.e., the linguistic manifestations) and conceptual antisemitism (the mindset): given the operation of language's semantic dimension, antisemitic language is always also and especially effective on an unconscious level; it always adds to the circulation in society of stereotypes and clichés, regardless of who utters it and whether it is articulated with or without antisemitic intent. ${ }^{18}$

Nor do educational attainment and the embrace of progressive ideals automatically prevent the production of Judeophobic verbal patterns, as the history of the Western world illustrates. Voltaire, Fichte, Hegel, Dickens, and many others were liberal-minded writers and men of learning, yet their works contain verbally explicit passages demonizing Jews. Knowing about the potential of antisemitic rhetoric to shape the collective consciousness, we should-indeed, we must, if we are serious about combating antisemitism in society at large-criticize and reject language that encodes Judeophobic tropes and combines with explosive catchwords. We have to do this without any exception and without regard to individual speakers and their educational background or point of view.

It is primarily academics from philological disciplines outside antisemitism studies as well as journalists and artists who downplay this crucial aspect or altogether brush it aside. On the subject of "modern Judeophobia," they cannot point to basic research or empirical studies to buttress their beliefs. All they have is the emotional intensity with which they proffer their "opinions." But opinions are no substitute for valid research findings that might be gained, for example, through quantitative and qualitative textual analyses conducted over

16 See, e.g., the historian A. Eckert, "Antisemitismus-Vorwürfe gegen Achille Mbembe: 'Anzeichen einer Hexenjagd'," SWR 2, April 22, 2020, https://www.swr.de/swr2/leben-und-gesell schaft/antisemitismus-vorwuerfe-gegen-achille-mbembe-anzeichen-einer-hexenjagd-104.html [no longer available], and the education scholar M. Brumlik in a broadcast of the television station 3sat: "Der Fall Mbembe," May 15, 2020, video, 6:32, https://www.3sat.de/kultur/kulturzeit/ der-fall-mbembe-100.html.

17 See, e.g., the pointers, references, and analyses at https://www.stopantisemitismus.de/. 18 See, e.g., M. Schwarz-Friesel, "Language and Emotion. The Cognitive Linguistic Perspective," in Emotion in Language. Theory-Research-Application, ed. U. M. Lüdtke (Amsterdam: John Benjamins, 2015), 157-73; and R. A. Friedman, "The Neuroscience of Hate Speech," New York Times, October 31, 2018, https://www.nytimes.com/2018/10/31/opinion/caravan-hate-speechbowers-sayoc.html. 
years. A familiar problem comes into view: amateur communication ${ }^{19}$ has long shaped the public debates around antisemitism, in which the denial and willful misinterpretation of anti-Israel antisemitism are characteristic. One stock argument that has again proved irresistible in the present instance is the truism that "comparing is legitimate in academic scholarship and does not amount to equating." That would be true-if the comparisons were based in fact and pertinent and not fantastic constructions upheld by catchwords from the repertoire of anti-Jewish rhetoric!

Yet nothing of the sort has happened. No cognitive progress has been made. Feelings rather than facts drive this discourse, which has turned into a fight for the prerogative of interpretation. The media and the public have in many ways reinforced that situation: instead of relying on categories proposed by experts and the relevant research, they give a platform to anyone who raises their voice, and the louder the better. The press prints, without critical comment, the remarks of educated laypeople on "antisemitism as general hostility toward humans," which is an utter falsehood, or reports on the IHRA's definition of antisemitism, which, for what it is worth, was developed by researchers of international renown..$^{20}$ Antisemitism, it bears emphasis, is hostility not toward humans but exclusively toward Jews. Jews are hated and stigmatized as Jews and not as a minority. ${ }^{21}$

19 Imagine a panel discussion with citizens, journalists, and politicians about possible therapies against tumor cells colonizing the brain to which no brain researcher or physician with a relevant specialization is invited. No one would take such a discussion very seriously. Yet that is exactly what happens almost on a weekly basis when it comes to antisemitism: publicists, journalists, activists, and others fill the screens and offer advice, ventilating possible causes and consequences. See also M. Schwarz-Friesel, "The Persistence of European Antisemitism," BESA Center Perspectives Paper, no. 1067, January 18, 2019, https://besacenter.org/per spectives-papers/european-anti-semitism/.

20 See, e.g., the following report on the IHRA definition: https://www.rosalux.de/publikation/ id/41168/gutachten-zur-arbeitsdefinition-antisemitismus-der-ihra, and its unequivocal rejection by antisemitism researchers. See D. Porat, "The Working Definition of Antisemitism-A 2018 Perception," in Comprehending and Confronting Antisemitism: A Multi-Faceted Approach, vol. 1 of An End to Antisemitism!, ed. A. Lange, K. Mayerhofer, D. Porat, and L. H. Schiffman (Berlin: De Gruyter, 2019), 475-88.

21 See, already, L. Poliakov, Bréviaire de la haine: Le IIIe Reich et les Juifs (Paris: Calman Levy, 1951); translated as Harvest of Hate: The Nazi Program for the Destruction of the Jews of Europe (Philadelphia: Talman, 1954). Antisemites see Jews not as one minority but as "THE others," a label that has the status of an epistemological category. Jews embody the opposite of the antisemite's own way of life and as such must be rejected and negated unconditionally and absolutely. See also Schwarz-Friesel, Judenhass im Internet, 33ff., 144ff. 
Nor does antisemitism have much in common with xenophobia: Jews were not and are not "foreigners" in the countries in which they live, having been well-integrated citizens for two centuries who have given no occasion for apprehensions of any kind. And Judeophobia is by no means correlated with an antimodern and reactionary worldview; on the contrary, it is found in left-wing progressives who embrace multiculturalism and reject nationalism, forward-looking champions of an enlightened modernity and equality who nonetheless indulge in anti-Jewish hatred of Israel "in the name of humanism." It follows that antisemitism must not be equated with racism (an equation that is expressed with particular frequency in the public discourse); it is also found among liberal-minded, educated people who espouse anti-racism. Their tolerance extends to all minorities and most idiosyncrasies, with one exception: the Jewish state.

\section{The Mbembe Controversy: A Case Study on the Distortion of Israel-related Jew-Hatred}

Returning to the Mbembe case, in May 2020, seven hundred African artists and intellectuals expressed in a letter to the German chancellor Angela Merkel their firm belief that the accusations against Mbembe were "mendacious" through and through and that all his critics were exponents of the hard right. ${ }^{22}$ Yet not even ten thousand signatures would undo the fact that Mbembe's writings attest to his irresponsibility in resorting to classical tropes of anti-Judaism. The debate reveals a serious and long standing problem: All public antisemitism debates of the past several years have demonstrated that for parts of German society, perceiving and acknowledging the reality and extent of contemporary Judeophobia is a massive challenge. Still, the fracas over Mbembe has revealed levels of ignorance and double standards that far exceed anything previously seen in this regard.

Achille Mbembe operates with the sort of surreal analogies and emotional superlatives that are characteristic of the verbal antisemitic patterns described above and that should have galvanized political leaders, the media, and civil society.

In the controversy over his utterances, Mbembe declared himself a victim of “German racism." He discredited the liberal politician Lorenz Deutsch with

22 Cf. "Offener Brief afrikanischer Intellektueller, Schriftsteller- und KünstlerInnen," issued May 18, 2020, accessed December 14, 2020, https://simoninou.files.wordpress.com/2020/05/ brief-von-afrikanischen_intellektuellen_an-die-dt-bundeskanzlerin_-angela-merkel.pdf. 
vague insinuations of contacts into the neo-Nazi scene and imputed the "devilish idea" of an "antisemitic negro" regarding himself. ${ }^{23}$ When the German government's commissioner for antisemitism, Felix Klein, ${ }^{24}$ criticized passages in Mbembe's writings, and pointed to serious research, Mbembe wrote that he would demand an apology "until my dying breath." ${ }^{25}$ In fact, there was only one character in this absurd situation who should have apologized promptly for the entire string of verbal missteps: Mbembe himself. Yet no such regret, which would have required the realization that he had employed dangerous and inadequate rhetoric, was forthcoming. After his self-justifying discourse (in which he took some liberties with the facts, as a commentator for the Frankfurter Allgemeine Zeitung pointed out ${ }^{26}$ ), he joined the fray, answering what he described in TAZ as a "giant smear campaign" with a round of self-pity and victim-blaming. He did not take back his anti-Israel statements. Is the "well-known and renowned scholar from Cameroon" 27 unaware of the dangerousness of certain verbal patterns? Does he need to use the terms "Pharisees" and "Zealots" (which were employed as antisemitic invectives for centuries) ${ }^{28}$ to label people whose views he does not accept? Does he need to quote the line "An eye for an eye, a tooth for a tooth," which is all over the antisemitic discourse? Does he really need to fabricate the charge of perpetrating an apartheid slur "worse than in South Africa" against the Jewish state, does he need to accuse it of "fanatical extermination," demand its "global isolation," and de-realize the "occupation of Palestine" as the "greatest moral scandal of our time"?29 What Mbembe is spreading are crude superlatives and extremist metaphors; there is no serious

23 A. Mbembe, “Gigantische Diffamierungskampagne," taz, May 11, 2020, https://taz.de/ Mbembe-zum-Antisemitismusvorwurf/!5684094/.

24 Felix Klein, the Commissioner for Jewish Life in Germany and the Fight against Antisemitism intervened in the case: Klein said that a person who has relativized the Holocaust should be barred from giving the festival's opening speech. As a consequence, many left intellectuals demanded his resignation. Mbembe himself claimed to be the victim of racism against Black people. 25 Mbembe, "Gigantische Diffamierungskampagne."

26 J. Kaube, "Wer hat Achille Mbembe gelyncht?,” Frankfurter Allgemeine, May 10, 2020, https:// www.faz.net/aktuell/feuilleton/debatten/antisemitismus-debatte-um-den-philosoph-achillembembe-16761907.html.

27 A. Posener, "Jörg Häntzschel oder die Unfähigkeit zur Selbstkritik," starke-meinungen.de, April 29, 2020, https://starke-meinungen.de/blog/2020/04/29/joerg-haentzschel-oder-die-un faehigkeit-zur-selbstkritik/.

28 G. Beyrodt, “Antisemiten sind immer noch die anderen,” May 1, 2020, https://www.deuts chlandfunkkultur.de/zur-causa-mbembe-antisemiten-sind-immer-noch-die-anderen.1079.de. html?dram:article_id=475841.

29 Mbembe, “On Palestine," viii. 
scholarship in it. The same holds true for many of his defenders, who at the same time show the practice of unique evaluation when it comes to Israel.

\section{Hubris and Moral Urge, Double Standard and Unique Focus: Giving Moral Advice to Jews and the Jewish State}

Hypothetical re-framing is a tool in cognitive science to reveal double standards and hypocrisy in discourse. Thus, let us imagine the following scenario: that the same statements above would have appeared in the writings, not of the scholar of post-colonialism Achille Mbembe, but in those of Alternative für Deutschland's right-wing Björn Höcke. ${ }^{30}$ How different the reactions would have been!

The thought experiment above reveals a marked double standard when it comes to right-wing and left-wing hostility toward Israel that we have long known from the debates around BDS: the same people who "declare war" on neo-Nazis and the radical right keep their eyes wide shut in the face of leftwing anti-Zionism and anti-Israelism. This is no way to combat antisemitism in society at large. As long as we measure the dissemination of antisemitic language and ideas by two different standards, any effort to fight Judeophobia will remain ineffective. In the present instance, this pattern is combined with the usual indignation theatrics-the "discussion around anti-Israel antisemitism" is said to detract from the "urgently needed battle against genuine antisemit-

30 Such hypothetical re-framing, which is to say, the placement of inherently problematic utterances in a different context, generally facilitates reflection on double standards in the assessment of antisemitic language and helps build awareness that it is the utterance as such that it is the source of danger and not (necessarily) the utterer. A similar thought experiment proved helpful in the debate around the anti-Israel poem by Günter Grass, who, for what it is worth, was a Nobel Prize-winning writer. See M. Schwarz-Friesel, "Dieser Text bedient moderne antisemitische Klischees," interview by K. Pokatzky, Deutschlandfunk Kultur, April 10, 2012, https://www. deutschlandfunkkultur.de/dieser-text-bedient-moderne-antisemitische-klischees.954.de.html? dram:article_id=147146. Antisemitic language has the potential to stigmatize and reinforce stereotypes by virtue of their semantic content. In other words, it is solely their signification that matters, not individuals and their intention, not their social status or ethnic background, and not the context. Human cognition has been shown to process language autonomously, which is to say, without regard to a speaker's intention and functional aspects (see above n. 13). The same, it should be noted, is true of racist language: that is why people who are sensitive to language do not use fraught terms such as negro, which automatically and uncontrollably trigger discriminatory connotations and associations. 
ism," critics supposedly engage in a "character assassination campaign" and rely on an "inappropriate construal of antisemitism"-to carry the moralizing to extremes. ${ }^{31}$ It brings out a "new German assertiveness" that both Jews and the state of Israel can and would prefer to do without. Frankfurter Rundschau, for example, opines that "Aleida Assmann ${ }^{32}$ has aptly characterized the conflict in these pages: 'A line now separates those who seek to support the State of Israel with their criticisms and make it better, from those who are determined to immunize it against any criticism [...]"'33 Of course, it is neither apt nor sensitive when finger-wagging Germans presume to "make" the Jewish state "better."

Statements like these should leave uneasy anyone who knows even a smidgen about the past and the history of Judeophobia. It is a sort of hubris that has been able to blossom because Germany has nursed the illusion of itself as an enlightened post-Holocaust society that has learned from the horrors of history and emerged chastened and reformed. Yet this supposedly comprehensive "cathartic" process never happened nationwide. As the historical and discourse-analytical scholarship of the past thirty years has documented at length, there was no genuine accounting for the past after 1945, no serious discussion about guilt and shame. What developed instead were blame-the-victim stratagems and a collective deflection of guilt based on the idea of innocent perpetrators. Building on this tradition, many left-wing and right-wing intellectuals have adopted a know-it-all mentality that is disconcerting. As though driven by a kind of missionary urge, these moralizing self-appointed humanists, enlightened thinkers, and responsible citizens address Jews and Israelis from the pedestal of their superiority, as is illustrated both by public statements and, even more clearly, by the steady stream of letters from academics-complete with names, addresses, and profiles outlining their qualifications-that the Central Council of Jews in

31 See, e.g., "Petition in Zeichnung-Abberufung des Antisemitismusbeauftragten Klein gefordert," issued May 3, 2020, accessed December 14, 2020, https://www.openpetition.de/petition/ blog/einspruch-gegen-sprachregelungen-fuer-hochschulen.

32 Aleida Assmann is a renowned cultural scientist who has contributed to the discourse on memory culture in Germany.

33 S. Hebel, "Missbräuchliche Indienstnahme," Frankfurter Allgemeine, May 5, 2020, https:// www.fr.de/kultur/gesellschaft/missbraeuchlicheindienstnahme-13751102.html. The quote comes from an essay in the Frankfurter Rundschau in which Assmann called the critical response to Mbembe's anti-Israel and antisemitic rhetoric "denunciation" and offers "proposals for a definition of antisemitism" without referring to the relevant scholarship by experts in the field, cf. A. Assmann, "Ein Klima des Verdachts, der Verunsicherung und der Denunziation," Frankfurter Allgemeine, May 4, 2020, https://www.fr.de/kultur/gesellschaft/klima-verdachts-verunsicherungdenunziation-13749410.html. 
Germany and the Israeli embassy in Berlin have received in recent years. ${ }^{34}$ Far from deriving an ethical or emotional principle of shame and humility from the "Holocaust experience," they turn things upside down, using the past to legitimize a peculiar inflated self-confidence vis-à-vis the descendants of the victims. They address Jewish citizens and Israelis the way a wise teacher might speak to immature children who have supposedly learned nothing from history (only too often, that is the collective reproach), giving advice and stern lectures, offering proposals on how to organize Israel and resolve the conflict with the Palestinians, and telling the Central Council how to behave. This hubris flows from the false peace that Germans have made with the history of the Holocaust, their treasured illusion of complete catharsis, their sometimes positively celebratory sense of having been reformed.

And there is no restraint in criticizing Israel because of the German past as often claimed. On the contrary: Germany's specific historic responsibility has become the fount of a universal aspiration-a kind of global ethics-for the present and the past: from now on, Germans will speak up against any and all forms of injustice and discrimination. There is no critical awareness that Israel and the Middle East conflict end up being the primary and often even the only objects of this guardian-of-virtue mentality. Repeating in mantra-like fashion that they have "learned the lessons of history" and are determined "never to be silent again in the face of suffering and oppression," these commentators demand that German Jews and Israelis "see reason at long last" and "show some humanity"35-in other words, they essentially suggest that the targets of their admonitions suffer from cognitive and emotional deficits. The Jewish people's history of suffering only serves to make its fall from grace the more dramatic: not even the Holocaust has transformed Jews into "morally upright humans who feel compassion for the Palestinians." ${ }^{36}$ It is hard to imagine a more explicit or more selfsatisfied coded inversion of the victim-perpetrator relationship. The recourse to anti-Judaic staples reveals the absurdity of these moralists' entire reasoning, demonstrating that they have in fact learned nothing from history: their use of

34 See the extensive discussion in the chapter "Hostility toward Jews as a Missionary Urge," in Schwarz-Friesel and Reinharz, Inside the Antisemitic Mind, $255 \mathrm{ff}$.

35 These formulas appear in hundreds of emails; see Schwarz-Friesel and Reinharz, Inside the Antisemitic Mind, 255ff. and 296ff.

36 One conspicuous feature of many of these letters is the contrast the writers draw between "good" and "bad" Jews: good Jews are those that were murdered in the Holocaust as well as those who condemn Israel, while those who like living in Israel and those who defend it are bad Jews; see ibid., 302ff. 
classic Judeophobic and anti-Jewish rhetoric only makes the fact more glaring that the catharsis they routinely claim to have gone through is a fiction.

To see why, consider that advice to Jews on how they need to behave, how they ought to live, how they should mimic the ways of the "good Christians" have a long tradition in the history of Western Judeophobia. Even well-meaning thinkers and politicians who were committed to the Enlightenment and the universal "good" and advocated the "emancipation" of the Jewish population (like the late eighteenth century's Abbé Grégoire and Christian Wilhelm von Dohm) found themselves incapable of accepting the "Jewish element" as it was and demanded its assimilation to the "good Christians." No one analyzed this primal core of Judeophobic resentment more trenchantly than Léon Poliakov in his book Bréviaire de la haine (1951, translated as Harvest of Hate) about the motivation behind the "Final Solution": that Jews were killed for the single reason that they were Jews. It was not social envy nor economic or social developments that led to catastrophe, as some claim, misrepresenting the cause of the Shoah, but the centuries-old hatred of Western anti-Judaism. The singular monstrosity: annihilating Jews for the benefit of humankind (as Himmler put it in his speeches). The same demand is now expressed with regard to Israel: in radical form, as the demand for the dismantlement of the Jewish state, or, cloaked in benevolence, as the call for a "change in the name of humanity." Where are these "humanist" voices when it comes to the true hot spots and hard issues of global politics: to Syria, Russia, Turkey, China, or Belarus, to name but a few? Yet the highly emotionalized single-minded focus is on Israel, a stable democracy. ${ }^{37}$ Disturbingly, this manifest double standard does not give people pause or wonder.

It is precisely because these voices come from within the educated elite that they are especially harmful, making effective efforts to combat the resurgent anti-Judaism that much more difficult: unlike right-wing radicals or populists (who, it is worth noting, raise exactly the same demands), they do not set off the alarm triggered by the vulgar Judeophobia of simpler minds; large parts of society listen to them, nod, and privately think to themselves with profound sat-

37 Israeli policies are widely and harshly criticized. The Jewish state is not unimpeachable. Instances of injustice, corruption, police violence, discrimination, controversial government action, nationalist decision-making occur in Israel as in any other country in the world. Such instances are reported in the media (and not least importantly in Israel's own press). What is crucial for the present discussion is not that criticism is expressed but which arguments are offered in its support and in which terms it is couched. Respectable critics, and there are many, do not resort to Nazi comparisons and Judeophobic tropes, nor do they preempt any possible charge of antisemitism with the communicative strategy of deflection and denial along the lines of "I'm not an antisemite, but ...". Legitimate criticism needs no such self-justification. 
isfaction: "Yes, Israel is terrible, why should it be unimpeachable, they're no better than the Nazis back in the day"-and effectively espouse a concept of the Jewish collective that is at the heart of antisemitic thought and sentiment. The result is growing support for the extremists, the radicals, the fundamentalists, and populists. It is growing support for extreme-right poster slogans like "Israel is our misfortune!"38

\section{Conclusion}

Classic anti-Judaism is by no means on the wane or mostly absent from contemporary communication (as a growing number of commentators has recently claimed)-the stereotypes and intense emotions on which Judeophobic resentment is based have lost none of their potency. Antisemitism is chameleonic, changing its outward manifestations over time, but its substance remains the same. Since the most frequent manifestation of contemporary antisemitism is encoded as anti-Israelism and camouflaged as "criticism of Israel," there is the danger of normalization of verbal antisemitism on all social levels in the public. We do see a double standard when it comes to antisemitism: It is strongly condemned when it comes from the Right, it is accepted when it comes from the Left (framed as "political criticism"). Comprehending and confronting antisemitism means standing up against all forms of Jew-hatred without looking at its origin. There can and must be no double standard when it comes to antisemitism. Over the past two decades, however, many academics and journalists have not only learned nothing from the debates over and research on contemporary anti-Judaism, they are even taking a disastrous step backwards on the urgently needed effort to expose such resentment for what it is.

Monika Schwarz-Friesel is a cognitive scientist, and she holds the chair of cognitive media linguistics at the Technical University of Berlin. In her research, she specializes on the mental patterns and verbal manifestations of contemporary antisemitism. Her publications include several books on antisemitism, for example, Inside

38 This intertextual slogan is based on the simple substitution of Israel for Jews. In Nazi Germany the slogan "The Jews are our misfortune!" was published as a headline on each Stürmer edition of the weekly antisemitic newspaper. The German far-right neo-Nazi party Die Rechte used it on their posters in the European election campaign in 2019. After several complaints against this antisemitic rhetoric, the German court of Hannover ruled that the slogan is legitimate. Once again, it became obvious that not all German institutions are able to cope properly with antisemitic slurs and actions. 
the Antisemitic Mind, with Jehuda Reinharz, 2017. Her current research deals with Jew hatred on the Web 2.0 and with the emotional dimension of Antisemitism.

Evyatar Friesel is professor (emeritus) of modern Jewish history at the Hebrew University of Jerusalem. His fields of research are the ideological trends in modern Jewry, the development of the Jewish national home in Palestine, the history of American Jewry, the history of German Jewry, and Jew-hatred in modern times. He was State Archivist of Israel from 1992 to 2001. Presently, he researches antiIsraelism among Jews.

\section{References}

Friedman, Richard A. "The Neuroscience of Hate Speech.” New York Times, October 31, 2018. https://www.nytimes.com/2018/10/31/opinion/caravan-hate-speech-bowers-sayoc.html.

Friesel, Evyatar. "The Inverted Ideological Pyramids of Anti-Zionist Jews: The Case of Moshe Zuckermann." BESA Center Perspectives Paper, no. 436, March 30, 2017, https://besa center.org/perspectives-papers/inverted-ideological-pyramids-anti-zionist-jews-casemoshe-zuckermann/.

Friesel, Evyatar. "Jews against Zionism/Israel: On the Ambivalences of Contemporary Jewish Identity." In Comprehending and Confronting Antisemitism: A Multi-Faceted Approach, vol. 1 of An End to Antisemitism!, edited by Armin Lange, Kerstin Mayerhofer, Dina Porat, and Lawrence H. Schiffman, 427-40. Berlin: De Gruyter, 2019.

Hirsh, David. Contemporary Left Antisemitism. London: Routledge, 2017.

Lange, Armin, Kerstin Mayerhofer, Dina Porat, and Lawrence H. Schiffman, eds. Comprehending and Confronting Antisemitism: A Multi-Faceted Approach, vol. 1 of An End to Antisemitism! Berlin: De Gruyter, 2019.

Nirenberg, David. Anti-Judaism: The Western Tradition. New York: Norton, 2013.

Poliakov, Léon. Bréviaire de la haine: Le IIle Reich et les Juifs. Paris: Calman Levy, 1951; translated as Harvest of Hate: The Nazi Program for the Destruction of the Jews of Europe. Philadelphia, Talman, 1954.

Porat, Dina. "The Working Definition of Antisemitism-A 2018 Perception." In Comprehending and Confronting Antisemitism: A Multi-Faceted Approach, vol. 1 of An End to Antisemitism!, edited by Armin Lange, Kerstin Mayerhofer, Dina Porat, and Lawrence H. Schiffman, 475-88. Berlin: De Gruyter, 2019.

Rensmann, Lars. “The Peculiar Appeal of the 'Jewish Question': The Case of Left Antisemitism." Antisemitism Studies 3, no. 2 (2020): 343-71.

Rensmann, Lars. "Zion als Chiffre: Modernisierter Antisemitismus in aktuellen Diskursen der deutschen politischen Öffentlichkeit." In Gebildeter Antisemitismus, edited by Monika Schwarz-Friesel, 93-116. Baden-Baden: Nomos, 2015.

Rosenfeld, Alvin H., ed. Anti-Zionism and Antisemitism: The Dynamics of Delegitimization. Indiana: Indiana University Press, 2019.

Schwarz-Friesel, Monika. "'Antisemitism 2.0'-The Spreading of Jew-hatred on the World Wide Web." In Comprehending and Confronting Antisemitism: A Multi-Faceted Approach, vol. 1 
of An End to Antisemitism!, edited by Armin Lange, Kerstin Mayerhofer, Dina Porat, and Lawrence H. Schiffman, 311-37. Berlin: De Gruyter, 2019.

Schwarz-Friesel, Monika. "Antisemitismus an Universitäten: die lange Tradition gebildeter Judenfeindschaft." Gender, Politik, Universität. Gegen Diskriminierung an Hochschulen 1 (2016): 22-23. http://www.audiatur-online.ch/2016/06/16/antisemitismus-an-uni versitaeten-die-lange-tradition-gebildeter-judenfeindschaft/.

Schwarz-Friesel, Monika. "Educated Anti-Semitism in the Middle of German Society: Empirical Findings." In Being Jewish in 21st-Century Germany, edited by Olaf Glöckner and Haim Fireberg, 165-87. Berlin: De Gruyter, 2015.

Schwarz-Friesel, Monika. Judenhass im Internet: Antisemitismus als kulturelle Konstante und kollektives Gefühl. Berlin: Hentrich \& Hentrich, 2019. English synopsis: https://www.lin guistik.tu-berlin.de/fileadmin/fg72/Antisemitism_2.0_short_version_final.pdf

Schwarz-Friesel, Monika. "Language and Emotion. The Cognitive Linguistic Perspective." In Emotion in Language. Theory-Research-Application, edited by Ulrike M. Lüdtke, 15773. Amsterdam: John Benjamins, 2015.

Schwarz-Friesel, Monika. "The Persistence of European Antisemitism." BESA Center Perspectives Paper, no. 1067, January 18, 2019. https://besacenter.org/perspectives-pa pers/european-anti-semitism/.

Schwarz-Friesel, Monika, and Jehuda Reinharz, eds. Inside the Antisemitic Mind. The Language of Jew-Hatred in Contemporary Germany. Boston: University Press of New England, 2017.

Schwarz-Friesel, Monika, and Jehuda Reinharz. "The Israelization of Antisemitism." The Jerusalem Post, February 16, 2017. https://www.jpost.com/opinion/the-israelization-of-an tisemitism-481835.

Shainkman, Mikael, ed. Antisemitism Today and Tomorrow: Global Perspectives on the Many Faces of Contemporary Antisemitism. Brighton: Academic Studies, 2019.

Stopantisemitimus.de. https://www.stopantisemitismus.de. Accessed December 14, 2020.

Wistrich, Robert. Antisemitism: The Longest Hatred. London: Thames Methuen, 1992.

Woldin, Philipp. “Die Medien kritisieren kaum ein Land so oft wie Israel." Zeit Online, August 4, 2017. https://www.zeit.de/politik/deutschland/2014-08/israel-medien-kritik. 